\title{
Pojam i ključna obilježja kompleksnih intervencija za populacije u riziku ${ }^{1}$
}

\section{Antonija Žižak*, Miranda Novak, Valentina Kranželić}

Odsjek za poremećaje u ponašanju, Edukacijsko-rehabilitacijski fakultet

Sveučilišta u Zagrebu

\section{Anita Jandrić Nišević, Irma Kovčo Vukadin}

Odsjek za kriminologiju, Edukacijsko-rehabilitacijski fakultet Sveučilišta u Zagrebu

Sažetak

Rad je dio projekta Specifična obilježja obitelji u riziku: doprinos razvoju kompleksnih intervencija, koji se provodi na Edukacijsko-rehabilitacijskom fakultetu Sveučilišta u Zagrebu, a financiran je od Hrvatske zaklade za znanost u okviru natječaja Istraživački projekti 2014. Cilj rada je istražiti, predstaviti i prodiskutirati različita razumijevanja kompleksnih intervencija i uz njih vezanih konstrukta i teorijskih pristupa. Krajnji cilj tog predstavljanja je konstruiranje operacionalne definicije koje će se u projektu koristiti. Pregled literature obuhvatio je radova koji se bave s jedne strane kompleksnim potrebama, problemima i populacijama, a s druge strane kompleksnim sustavima i intervencijama u području odgoja i obrazovanja, socijalne skrbi, pravosuđa i zdravstva. Nakon analize postavljene su operacionalne definicije pojmova kompleksne (indiviualne i obiteljske) potrebe i kompleksne intervencije te su generirane smjernice za planiranje i provedbu istraživačkog dijela projekta.

Ključne riječi: kompleksne potrebe; kompleksne populacije; kompleksne intervencije.

1 Ovaj je rad financirala Hrvatska zaklada za znanost projektom IP-2014-09-9515.

Autor za korespondenciju: Antonija Žižak, Odsjek za poremećaje u ponašanju, Edukacijsko-rehabilitacijski fakultet Sveučilišta u Zagrebu, e-mail: antonija.zizak@erf.hr 
Antonija Žižak, Miranda Novak, Valentina Kranželić, Anita Jandrić Nišević, Irma Kovčo Vukadin: Pojam i ključna obilježja kompleksnih intervencija za populacije u riziku

\section{UVOD}

Konstrukt kompleksne intervencije jedan je od konstrukta na kojima se temelji projekt Specifična obilježja obitelji u riziku: doprinos razvoju kompleksnih intervencija. lako je kompleksne intervencije moguće posredno povezati sa svim specifičnim ciljevima projekta, ta veza najbolje dolazi do izražaja u drugom i sedmom cilju koji glase:

(2) Utvrditi opća i posebna obilježja obitelji u kojima je najmanje jedan član zbog specifičnih rizika/problema u ponašanju korisnik intervencije u području obrazovanja, socijalne skrbi, mentalnog zdravlja i/ili pravosuđa.

(7) Definirati smjernice za planiranje (kompleksnih) intervencija s obiteljima u riziku temeljem korisničke perspektive te diseminirati rezultate istraživanja i smjernice.

Kako je projekt usmjeren na istraživanje obilježja obitelji izloženih različitim vrstama_rizika te članova obitelji uključenih u različite vrste intervencija koje se provode u različitim intervencijskim kontekstima i sustavima, važno je razmotriti kako se pojam i koncept kompleksne intervencije razumiju i koriste u pojedinim intervencijskim kontekstima (sektorima ili područjima društvenog djelovanja).

Pregled literature ukazuje na neujednačeno korištenje ovog termina u stručnim područjima na koja se projekt usmjerava. Najprisutniji je u literaturi iz bio-medicinskog područja (Craig i sur., 2008), dok se u literaturi iz društvenog područja, osobito obrazovanja i socijalne skrbi, javlja rjeđe iako se pojavljuje relativno rano i kontinuirano (Brown, 1992; Byrne, 1998; Gorard i Taylor, 2004; Davis, 2008; Egan i sur., 2009; Snyder, 2013). Pregledom literature u području pravosuđa nije zabilježeno korištenje ovog pojma. Stoga je cilj ovog rada istražiti različita razumijevanja kompleksnih intervencija, konstrukta i teorijskih polazišta na kojima počivaju te predstaviti operacionalnu definiciju kompleksnih intervencija koja će se u projektu koristiti.

Uvodno treba nešto reći o etimologiji pojma kompleksnost i kompleksne intervencije. Riječi kompleksnost u pravilu se odnosi da ono što sadržava više elemenata. Za ovaj rad je značajno kako se razumijevanje tog pojma tijekom vremena mijenjalo u znanstveno-teorijskom prostoru. U tom smjeru osobito je važna analiza Alhadeff-Jones (2008) koji govori o tri generacije teorije kompleksnosti i kroz to o promjeni značenja pojma kompleksno u znanosti. Radi se o pristupima koji na kompleksnost gledaju kao na: 
Antonija Žižak, Miranda Novak, Valentina Kranželić, Anita Jandrić Nišević, Irma Kovčo Vukadin: Pojam i ključna obilježja kompleksnih intervencija za populacije u riziku

- suprotnost jednostavnosti kada se kompleksnim fenomenima pristupa redukcionistič$\mathrm{ki}$ - reduciranjem na jednostavnije sastavne dijelove koji se mogu izolirano izučavati.

- fenomen koji objedinjuje neuređene/neorganizirane fenomene. Najčešće se koristi u prirodnim znanostima, gdje se kompleksnosti organizacijski i modelski pristupa te nastaju statistički i probabilistički modeli, odnosno govori se o "neorganiziranoj kompleksnosti”.

- pojam koji opisuje vrlo komplicirane fenomene koje nije moguće objasniti kroz prethodne metrike. To je suvremeno razumijevanje pojma potaknuto iz biologije, medicine, psihologije i drugih društvenih znanosti. Radi se o fenomenima "organizirane kompleksnosti", odnosno problemima koji uključuju istovremeno bavljenje s velikim brojem faktora koji su povezani u 'organsku' cjelinu, a metodologija njihovog istraživanja još se razvija.

Među prvim relevantnim izvorima koji koriste i operacionaliziraju sintagmu 'kompleksne intervencije' je britanski Medical Research Council (prema Campbell i sur., 2000). Obrazloženje je objavljeno u pregledu modela za evaluaciju kompleksnih intervencija 2000. godine, uz napomenu da nema jasne granice između jednostavnih i kompleksnih intervencija. Polazeći od činjenice da postoji mali broj intervencija koje su zaista jednostavne, naglašava se potreba za intervencijama koje se sastoje od nekoliko komponenata koje su u međusobnoj interakciji, namijenjene su različitim grupama ili ciljnim skupinama, imaju višestruke ishode te se fleksibilno prilagođavaju kontekstu u kojem se provode.

\section{KOMPLEKSNE POTREBE I KOMPLEKSNE POPULACIJE}

Pri razmatranju intervencija koje se planiraju i poduzimaju s osjetljivim skupinama uobičajeno se u fokus stavljaju obilježja tih skupina i njihove specifične potrebe za određenim intervencijama koje organizira, omogućava i pruža jedna ili više javnih, civilnih ili privatnih institucija ili službi. Mehanizmi usklađivanja određene intervencije sa specifičnim potrebama ciljne skupine uključuju dobro poznavanje tih potreba te drugih obilježja, kako ciljne skupine tako i same intervencije. Literatura upućuje da ista načela slijede i postupci planiranja kompleksnih intervencija, koje se vezuju uz kompleksne potrebe i probleme, odnosno kompleksne populacije. 
Antonija Žižak, Miranda Novak, Valentina Kranželić, Anita Jandrić Nišević, Irma Kovčo Vukadin: Pojam i ključna obilježja kompleksnih intervencija za populacije u riziku

\section{Što su i kako se razumiju kompleksne potrebe?}

Analiza literature (Rankin i Regan, 2004; Bromfield, Sutherland i Parker, 2012; Terra, Scott i Khan, 2015; The Calouste Gulbenkian Foundation and Makin Every Adult Matter, 2015) ukazuje da se pojam kompleksne potrebe istovremeno odnosi na širinu ili brojnost te dubinu ili ozbiljnost potreba. Širina uključuje više, međusobno isprepletenih i povezanih potreba, dok se dubina odnosi na razine osnovnih, specifičnih, prioritetnih potreba, njihov intenzitet odnosno važnost za pojedinca.

Pojam se ponekad koristi za osobe s višestrukim potrebama, a ponekad za osobe kojima je, prema mišljenju stručnjaka, najteže pomoći. Stoga, postoji neizvjesnost pri njegovom korištenju u smislu dileme: jesu li potrebe kompleksne zato što ih postojeće usluge (intervencije) ne mogu zadovoljiti ili intervencije nisu djelotvorne zato što su potrebe tako složene (Rankin i Regan, 2004).

Rosengard i sur. (2007) konstatiraju da se koncepti 'višestruko' i 'kompleksno' koriste u različitim disciplinama. Samo ponekad koristi se jedan od njih s vrlo specifičnim značenjem i namjerom. Najčešće se koriste zamjenično. Ti koncepti uključuju: višestruku ugroženost, višestruke teškoće, višestruka oštećenja, višestruke dijagnoze, potrebu za širokom i intenzivnom pomoći, kompleksne zdravstvene potrebe te višestruke i složene potrebe. Tako se pokrivaju sljedeći aspekti potreba/ problema:

Širina: više problema i više aspekata jednog problema (odnosi se primjerice na probleme koje imaju osobe sa sljedećim značajkama: invaliditet, mentalno-zdravstveni i drugi zdravstveni problemi, problemi stanovanja - beskućništva, zatim izbjeglice, tražitelji azila, žrtve nasilja i zlostavljanja).

Dubina: osnovne potrebe, teška ili dugotrajna oštećenja i invaliditet (odnosi se primjerice na probleme koje imaju osobe sa sljedećim značajkama: teškoće u učenju, govorno jezične teškoće, teškoće vida i sluha, mentalno-zdravstveni problemi).

Višestruki problemi za pružatelje pomoći/usluga (odnosi se primjerice na: djecu s teškoćama u razvoju uključenu u redovite škole; djecu s problemima u ponašanju i emocijama uključenu u redovite škole).

Višestruka ugroženost (uključuje kombinaciju više problema među kojima su primjerice: siromaštvo, nezaposlenost, loše stambene uvjete, probleme pismenosti, visoki rizik od izloženosti utjecaju kriminala). 
Antonija Žižak, Miranda Novak, Valentina Kranželić, Anita Jandrić Nišević, Irma Kovčo Vukadin: Pojam i ključna obilježja kompleksnih intervencija za populacije u riziku

Višestruke potrebe povezane $\mathbf{s}$ dobi i tranzicijama (odnosi se primjerice na: mlade i stare osobe u vrijeme tranzicije - napuštanja obitelji, odlazak iz institucije, iznenadne teške/dugotrajne bolesti, invaliditet, nesposobnost).

Svi ljudi imaju višestruke i kompleksne potrebe. Međutim, kad se u stručnoj literaturi termin koristi kao što je prethodno opisano, on se primarno odnosi na osobe koje se susreću s različitim, višestrukim problemima pa prema tome i s različitim i brojnim pružateljima usluga i pomoći (Keene, 2001, Rankin i Regan, 2004, Bromfield, Sutherland i Parker, 2012). Država Viktorija (Australija) je 2009. godine donijela zakon o uslugama za osobe s kompleksnim potrebama (Human Services [Complex Needs] Act 2009) kojim se propisuje način uspostavljanja usluga za osobe s kompleksnim potrebama u sustavima socijalne skrbi, zdravstva, mentalnog zdravlja, usluga i pomoći osobama s invaliditetom, tretmana zlouporabe sredstava ovisnosti i alkohola, stanovanja i podrške. Prema tom zakonu, za osobu s kompleksnim potrebama može se kvalificirati osoba koja (je):

a) navršila 16 godina života,

b) zadovoljava dva ili više od sljedećih kriterija:

- ima dijagnozu mentalne bolesti (prema važećoj klasifikaciji)

- zadobila je povredu mozga

- ima intelektualne teškoće

- zlorabi alkohol ili druga sredstva ovisnosti,

c) pokazuje nasilno ili opasno ponašanje kojim čini ozbiljnu štetu sebi ili drugima ili se ponaša na način koji nju ili druge može dovesti u rizične situacije,

d) treba intenzivan nadzor i podršku i koja bi imala koristi od ko-ordiniranih usluga koje mogu uključivati usluge socijalne skrbi, zdravstvene i mentalno zdravstvene usluge, usluge namijenjene osobama s invaliditetom, tretman zlouporabe alkohola i sredstva ovisnosti ili stanovanja i usluge podrške.

Kad su u pitanju obitelji, situacija je slična. Govori se o obiteljima s višestrukim problemima (Kendal, Rodgers i Palmer, 2010), obiteljima s višestrukim i kompleksnim potrebama (Bromfield, Sutherland i Parker, 2012), odnosno specifičnim potrebama obitelji s iskustvom višestrukih teškoća (Morris i sur., 2008). I ovdje su teškoće, potrebe, problemi vezani uz ista područja - mentalnog zdravlja, zlouporabe sredstava ovisnosti i alkohola, skrbi o djeci i maloljetnim roditeljima, kriminala i antisocijalnog ponašanja te nasilničkog ponašanja. Prema Hoagwood (2005.) neki od najznačajnijih 
Antonija Žižak, Miranda Novak, Valentina Kranželić, Anita Jandrić Nišević, Irma Kovčo Vukadin: Pojam i ključna obilježja kompleksnih intervencija za populacije u riziku

prediktora za svrstavanje obitelji u skupinu obitelji s kompleksnim potrebama (visokorizične obitelji) jesu: loš socijalno-ekonomski status, status etničke manjine, ozbiljnost djetetovih teškoća/problema te roditeljski stres i depresija. Međutim, članovi takvih obitelji ne doživljavaju svoju obiteljsku situaciju tako teškom i složenom kao što bi stručnjaci i istraživači očekivali (Maras i sur., 2008). Uz to, Rosengard i sur. (2007) na temelju pregleda literature ističu da osobama s kompleksnim potrebama u pravilu nedostaju informacije i znanja o odgovarajućim, postojećim intervencijama.

Bromfield, Sutherland i Parker (2012) konstatiraju da su kompleksne potrebe obitelji povezane sa socijalnim, ekonomskim i strukturnim rizicima te da ih treba razumijevati kroz višestruke perspektive, odnosno međusobnu povezanost socijalnih, povijesnih, trans-generacijskih i kulturnih faktora. Pritom naglašavaju kako rizici djeluje u više smjerova te se pojavljuje kao prethodni ili posljedični činitelj siromaštva i socijalne isključenosti.

U najčešće spominjane ugroze / rizike / nedaće / razloge socijalne isključenosti pripadaju: siromaštvo, loši stambeni uvjeti, zdravstveni problemi, slabe obrazovne mogućnosti, nedostatne vještine (različitog tipa), slabe mogućnosti zapošljavanja, nedostatak socijalnog kapitala, nedostatak obiteljske i podrške iz zajednice, kriminal, mentalno-zdravstveni problemi, zlouporaba sredstava ovisnosti, nasilje, traume u ranom djetinjstvu te iskustvo s roditeljima niskih roditeljskih kompetencija. Pojedinačni, specifični rizici međusobno se isprepliću i rezultiraju socijalnom ugroženošću i isključenošću. Time individualne i socijalne teškoće/problemi postaju neraskidivo međuzavisne. Vrlo je vjerojatno da će cikličko ponavljanje siromaštva i ugroženosti, osobito u kombinaciji s ranim traumatizacijama pojedinca, rezultirati međugeneracijskim prijenosom kompleksnih potreba/ problema, kako pojedinaca, tako i obitelji. Slijedom navedenog, obitelji s kompleksnim potrebama imaju kronične, duboko ukorijenjene i međusobno povezane probleme. Stoga ima smisla (logike i potrebe) na te probleme/potrebe odgovoriti 'združivanjem' pojedinačnih pokušaja različitih dijelova društva (sektora) kako bi se osmislili programi prikladni da odgovore na kompleksne potrebe obitelji.

Za ovo je istraživanje osobito značajno kako identificirati i procijeniti kompleksne potrebe obitelji. Kendal, Rodgers i Palmer (2010) konstatiraju da postoje brojni modeli procjene potreba obitelji te da se najčešće utvrđuju na lokalnoj razini. Pritom prevladava princip procjene specifičnih potreba pojedinih članova obitelji unutar specifičnog obiteljskog okruženja. Procjena je uvijek u funkciji izbora odgovarajuće intervencije. U tom smislu Katz, Spooner i Valentine (2006) naglašavaju da se za obitelji s kompleksnim problemima istovremeno s procjenom značajki, potreba i želja obitelji, što se uobičajeno odvija prije uključivanja u intervenciju, odgovara na trenutne / hitne potrebe za specifičnom podrškom. 
Antonija Žižak, Miranda Novak, Valentina Kranželić, Anita Jandrić Nišević, Irma Kovčo Vukadin: Pojam i ključna obilježja kompleksnih intervencija za populacije u riziku

Prema načelu da tamo gdje postoji nezadovoljena potreba(e) postoji i problem(i), kao zamjenski termin za kompleksne potrebe može se koristiti termin višestruki i složeni problemi. Primjerice, kako bi naglasila složenost i zahtjevnost kompleksnih potreba Keene (2001) koristi oba pojam zajedno u sintagmi 'klijenti s kompleksnim problemima i psihosocijalnim potrebama'.

S druge strane, literatura koja se bavi definiranjem problema iz perspektive teorije kompleksnosti (Glouberman i Zmmerman, 2002, prema Snyder, 2013) razlikuje vrste problema prema njihovoj složenosti. Kompleksne probleme definira u odnosu na jednostavne i komplicirane. I dok je rješavanje jednostavnih problema omogućeno postupanjem "po receptu“ jer se na taj način svaki put dolazi do standardizirano dobrog rješenja (proizvoda), dotle je za rješavanje kompliciranih problema potrebna visoka razina ekspertnosti stručnjaka u području u kojem se problem javlja, a uspjeh u rješavanju problema ovisi o kvaliteti i preciznosti procedura te istreniranosti onih koji problem rješavaju. Kompleksni problemi su takve cjeline iz kojih se teško odvajaju pojedini dijelovi jer je suština problema u vezama i odnosima među dijelovima, a ne u pojedinom dijelu. Kao primjer kompleksnog problema u literaturi se najčešće navodi odgoj djeteta. Na tom primjeru ukazuje se na ograničene domete poznatih, prosječnim problemima namijenjenih, osobito rigidnih, metoda njihovog rješavanja. Snyder (2013) napominje da se probleme, odnosno pitanja u području društvenih znanosti često smatra kompliciranima, a zapravo se radi o kompleksnim problemima. $U$ tu kategoriju pripadaju zato što za njih nema unaprijed poznatog odgovora / rješenja, nego se on mora "dogoditi" u procesu njegovog traženja. Zato se kod rješavanja kompleksnih problema radi unutar okvira "neistraženih nepoznanica".

Pregledom literature na temu višestrukih i kompleksnih potreba Rosengard i sur. (2007) zaključili su da:

- ne postoji usuglašenost oko definicije višestrukih i kompleksnih potreba, odnosno da se ti termini koriste u različitim značenjima, vrlo često bez definiranja tog značenja, odnosno kad je opisano, značenje tih termina vezuju se uz ciljeve istraživanja ili donositelja odluka;

- značenje ovih termina (zajedno ili odvojeno) pokriva, kako širinu i različitost potreba, tako i kontinuum potreba, odnosno "ekstremnost" neke potrebe;

- termini se rabe da bi opisali intenzivne i međusobno povezane potrebe u odnosu na neko stanje. Kad se tako koriste to reflektira medicinski model $\mathrm{i}$ individualizirane tretmanske strategije premošćivanja intervencijskih praznina;

- rabe se u smislu višestrukih i međusobno povezanih mehanizama, ugroza ili nedostataka. Takvo korištenje odražava usklađenost sa socijalnim modelom, koji je inače usmjeren 
Antonija Žižak, Miranda Novak, Valentina Kranželić, Anita Jandrić Nišević, Irma Kovčo Vukadin: Pojam i ključna obilježja kompleksnih intervencija za populacije u riziku

na dimenziju uključivanje - isključivanje, nastojeći procijeniti načine na koje sustavi i njegovi dijelovi ne uspijevanju zadovoljiti potrebe te koje su strateške, institucionalne ili organizacijske promjene potrebne da se premoste nedostaci;

- termini se rabe kako bi se ukazalo na stupanj ili intenzitet, složenost i međusobnu povezanost potrebe. Kad se tako koriste termini su u funkciji postavljanja okvira za politiku stručnih prioriteta, smjernica postupanja i usmjeravanja sredstava.

Način uporabe ovih termina ima značajnog utjecaja na to kako se identificiraju nedostaci, odnosno praznine u intervencijskom sustavu, kako se identificiraju dobre prakse te budući strateški smjerovi razvoja intervencija. Stoga je u ovom istraživanju potrebno definirati njihovo specifično značenje u vidu radne definicije.

\section{Kompleksne populacije}

Što se tiče kompleksne populacije jednostavan je zaključak da osobe s višestrukim i kompleksnim potrebama/ problemima mogu biti označene kao 'kompleksna populacija'. Rosengard i sur. (2007) navode primjere istraživanja koja su unutar te populacije dovela do prepoznavanja onog dijela populacije kojeg je moguće imenovati isključenom i teško dostupnom za intervencije ('excluded and hard to reach). To osobito uključuje mlade konzumente sredstava ovisnosti, počinitelje kaznenih djela, isključene iz obrazovnog procesa ili osobe koje su prethodno bile u javnoj skrbi.

Kada su u pitanju obitelji s kompleksnim potrebama / problemima Thoburn (2009) koristi termin teško dostupne i teško promjenljive (hard to reach and hard to change).

Keene (2001) ističe da osobe s kompleksnim problemima i psihosocijalnim potrebama 'obilaze' razne institucije i stručnjake te koriste disproporcionalno mnogo sredstava a da pritom za sebe ne dobiju adekvatan oblik pomoći i podrške. Kako bi napravila jasan pregled kompleksne populacije autorica koristi sljedeću klasifikaciju: 
Antonija Žižak, Miranda Novak, Valentina Kranželić, Anita Jandrić Nišević, Irma Kovčo Vukadin: Pojam i ključna obilježja kompleksnih intervencija za populacije u riziku

\begin{tabular}{|c|c|}
\hline Vrsta problema & Opis \\
\hline $\begin{array}{l}\text { Psihološki, mentalno } \\
\text { zdravstveni i } \\
\text { drugi problemi }\end{array}$ & $\begin{array}{l}\text { Kombinacije uključuju emocionalne i ponašajne probleme } \\
\text { adolescenata, suicid, depresiju, PTSP, zlouporabu sredstava } \\
\text { ovisnosti, alkoholizam, ADHD, fobije. }\end{array}$ \\
\hline $\begin{array}{l}\text { Teškoće u učenju i druge } \\
\text { razvojne teškoće }\end{array}$ & $\begin{array}{l}\text { Teškoće u učenju javljaju se u kombinacija s problemima u } \\
\text { ponašanju, fizičkom agresijom, psihijatrijskim dijagnozama, } \\
\text { samoozljeđivanjem. }\end{array}$ \\
\hline $\begin{array}{l}\text { Socijalni problemi, } \\
\text { beskućništvo i drugi } \\
\text { problemi }\end{array}$ & $\begin{array}{l}\text { Istraživanja pokazuju da se beskućništvo često javlja u } \\
\text { kombinaciji s mentalno-zdravstvenim problemima, problemima } \\
\text { zlouporabe sredstava ovisnosti, osobito alkohola, činjenjem } \\
\text { kaznenih djela te hospitalizacijom. }\end{array}$ \\
\hline Kriminal i drugi problemi & $\begin{array}{l}\text { Uz vršenje kaznenih djela vezuju se nezaposlenost, zlouporaba } \\
\text { sredstava ovisnosti, hostilnost, nasilničko ponašanje te različite } \\
\text { psihijatrijske dijagnoze. }\end{array}$ \\
\hline $\begin{array}{l}\text { Zlouporaba sredstava } \\
\text { ovisnosti i alkohola i drugi } \\
\text { problemi }\end{array}$ & $\begin{array}{l}\text { Najčešće dolazi u kombinaciji s psihološkim problemima } \\
\text { i problemima mentalnog zdravlja, socioekonomskim i } \\
\text { problemima stanovanja. }\end{array}$ \\
\hline
\end{tabular}

Kao što je već napomenuto, projekt je usmjeren na istraživanje obilježja otpornosti obitelji i članova obitelji koji imaju potrebu(e) za intervencijama na području obrazovanja, mentalnog zdravlja, tretmana alkoholizma i ovisnosti, skrbi i tretmana djece/mladih s problemima u ponašanju te sankcioniranja i tretmana počinitelja kaznenih djela različitih dobnih skupina. Stoga su u okviru što slijedi sažeto prikazani kompleksni problemi osoba koje pripadaju u neke od tih kompleksnih populacija i njihovih obitelji.

Na temelju opsežne analize obilježja obitelji za različite vrste visokorizičnih obitelji Morris i sur. (2008) su kao rizike u području obitelji za maloljetne počinitelje kaznenih djela izdvojili:

- veći broj čimbenika rizika u vrijeme rođenja djeteta (niža porođajna težina, perinatalne teškoće, okolnosti koje određuju je li se dijete rodilo u nepovoljnim, teškim uvjetima i okolnostima);

- $\quad$ priprema za roditeljstvo i roditeljsko ponašanje neposredno nakon poroda (vezano uz zlouporabu sredstava ovisnosti, maloljetni roditelji, nedostatak osnovnih roditeljskih vještina); 
Antonija Žižak, Miranda Novak, Valentina Kranželić, Anita Jandrić Nišević, Irma Kovčo Vukadin: Pojam i ključna obilježja kompleksnih intervencija za populacije u riziku

- pitanja roditeljskog nadzora, najčešće u vidu jednog od dva ekstrema - strogi i kruti ili pasivni i zanemarujući roditeljski odgoj;

- sukobi u obitelji, osobito bračni sukobi (puno značajniji od strukture obitelji);

- obiteljska povijest i roditeljski stavovi koji podržavaju antisocijalno i kriminalno ponašanje;

- kombinacija niskih prihoda obitelji, loših stambenih uvjeta, stresa uzrokovanog lošom materijalnom situacijom, nedostatkom resursa i veličina obitelji.

Orford i suradnici (2010, prema Moesgen i Klein, 2015) sumiraju istraživanja i navode specifičnosti obitelji u kojima je odrasli član ovisnik o drogama:

- odnosi u obitelji postali su neskladni, ponekad i agresivni (primjerice: osoba koja koristi sredstva ovisnosti malo ili rijetko sudjeluje u obiteljskom životu, iskazuje neobjašnjive promjene u ponašanju, izoliranost, čestu agresivnost, laganje te ponekad lažno optužuje druge;

- sukobi vezani uz novac i imovinu (primjerice: nedostatak novca za redovito obiteljsko funkcioniranje, osobito kod kockanja);

- iskustvo neizvjesnosti (primjerice: nepouzdana prisutnost člana obitelji koji je ovisnik, «dolasci i odlasci», izostajanje s dogovorenih obiteljskih obveza, dolazak kući u nepredvidljivim vremenima i stanjima);

- zabrinutost članova obitelji (primjerice: zabrinutost oko konzumiranja sredstva ovisnosti, društva, mentalnog i fizičkog zdravlja, sigurnosti i posla/karijere);

- dom i obiteljski život su u opasnosti (primjerice financijska situacija, neugodna obiteljska klima, utjecaj na dobrobit djece, fizički integritet i sigurnost);

- ograničen uobičajeni socijalni život (primjerice: izbjegavanje ugodnih druženja i događanja, zabrinutost oko ponašanja člana-ovisnika, strah od kritiziranja drugih).

Prema (Gampell, Scharff-Smith, 2011) problemi s kojima se susreće obitelj tijekom izvršavanja zatvorske kazne člana obitelj, mogu se razvrstati u osam skupina. Svaku od tih skupina problema istraživao je veći broj autora. Problemi se odnose na:

- ugrožene potrebe i prava djece uz nedovoljnu formalnu podršku (djeca zatvorenika se često nazivaju "zaboravljena djeca" ili "skrivene žrtve", "nevidljive žrtve kriminaliteta i 
Antonija Žižak, Miranda Novak, Valentina Kranželić, Anita Jandrić Nišević, Irma Kovčo Vukadin: Pojam i ključna obilježja kompleksnih intervencija za populacije u riziku

penalnog sustava") (Bernstein, 2003, Jelavić, 2009; Hisel i sur. , 2011; Philbrick i sur., 2014; Robertson, 2007; King, 2002);

- $\quad$ promjene u strukturi obitelji (promjene u sustavu odgoja, podrške i skrbi za dijete, obiteljskih odnosa, financijskog stanja obitelji; povećani pritisak na članove šire obitelji - bake i djedove, povećani roditeljski stres, povećani rizik od razdvajanja roditelja nakon otpusta) (Profaca i Buljan Flander, 2009; Loper i sur., 2009; Loper i sur., 2015; Markson i sur., 2015; Robertson, 2007, Gampell, Scharff-Smith, 2011);

- teškoće održavanja odnosa (promjena odnosa roditelja i djece, teškoće u kontaktima, dileme oko zabrane kontakta djeteta s roditeljem za vrijeme izdržavanja kazne) (Blumberg i Griffin, 2013; King, 2002; Gampell, Scharff-Smith, 2011);

- zdravlje (depresivni simptomi, anksioznost, emocionalni problemi, ljutnja, hostilnost, post-traumatski stres, zlouporabu sredstava ovisnosti, probleme spavanja, smanjena koncentracija) (Bülow, 2014; Loper i sur., 2015; Phillips i sur., 2002; Murray i Farrington, 2008; Poehlmann, 2005; Hissel i sur., 2011; Murray i sur., 2009; Murray i sur., 2012);

- financijske teškoće (smanjen broj izvora zarade, povećani troškovi, rizik od gubitka socijalne pomoći) (Bülow, 2014; ; Loper i sur., 2015; Robertson, 2007; King, 2002; Gampell, Scharff-Smith, 2011);

- dječja svijest o tome da je roditelj u zatvoru (skrivanje istine od djece, sram, neadekvatna objašnjenja roditeljske odsutnosti, ambivalentnost, zabrinutost za roditelja, podcjenjivanje i odbacivanje od strane vršnjaka) (Loper i sur., 2015; prema Profaca, Buljan Flander, 2009; King, 2002; Gampell, Scharff-Smith, 2011);

- $\quad$ stigmatizacija i socijalna izolacija (dodatni stres, skrivanje istine pred prijateljima i poznanicima, agresija prema onima koji stigmatiziraju, strah da će drugi misliti da su loši ljudi zato što su u rodu s nekim tko je u zatvoru) (Murray, 2007; King, 2002; Genty, 2012; Rosenberg, 2009);

- $\quad$ posjete u zatvoru (pomiješani osjećaji vezano uz posjete roditelju u zatvoru, otežano komuniciranje u obitelji, doživljaj osobe u zatvoru kao stranca) (Casey-Acevedo i sur., 2004; Benning i Lahm, 2016; De Claire i Dixon, 2015; Gabelica Šupljika, 2009; King, 2002). 
Antonija Žižak, Miranda Novak, Valentina Kranželić, Anita Jandrić Nišević, Irma Kovčo Vukadin: Pojam i ključna obilježja kompleksnih intervencija za populacije u riziku

\section{KOMPLEKSNE INTERVENCIJE}

Pri proučavanju intervencija kontinuirano se pojavljuje više izazova. Dva su osobito značajna za ovo istraživanje.

Prvi se odnosi na višestruko značenje pojma intervencija koje uključuje aktivnosti, programe, mjere, tretmane, strategije te postupke i kompetencije za njihovu primjenu (O'Hare, 2009). Ta se značenja multipliciraju kad se u obzir uzmu tumačenja različitih profesija uključenih u planiranje, provedbu i evaluaciju intervencija u područjima kao što su zdravstvo, odgoj i obrazovanje, socijalna skrb, pravosuđe i civilni sektor. U ovom istraživanju na taj izazov odgovarati će se kreiranjem operacionalne definicije kompleksnih intervencija.

Drugi izazov odnosi se na opisivanje intervencije, osobito u znanstveno-istraživačke svrhe. Primjerice, Michie i sur. (2009) navode da su u analizi 1.000 studija usmjerenih istraživanju ishoda promjene ponašanja, intervencije poduzete s tim ciljem bile dostatno opisane samo u 5\% do 30\% studija. Ta nedorečenost osobito se odnosi na opisivanje ključne (funkcionalne, aktivne) komponente intervencije, odnosno one komponente koja je temeljna za ostvarenje planiranih promjena, odnosno ishoda². Kako bi se unaprijedilo znanstveno utemeljeno razumijevanje doprinosa intervencije promjeni ponašanja nužno je izučavati vezu između teorija promjene i razvoja, odnosno evaluacije intervencije (Michie i Prestwich, 2010; Michie i Johnston, 2012). Stoga su istraženi različiti modeli opisivanja i razumijevanja ključnih obilježja/ varijabli/ dimenzija intervencije i načina njihovog opisivanja u stručne i znanstvene svrhe (Whittaker, J.K. i Tracy, 1989, Cohen, 1995, Hoge, 1999, Michie i sur., 2009, Albrecht i sur., 2013). Nakon analize, kao najsuvremenije prihvaćene su WIDER ${ }^{3}$ preporuka za unapređenje izvještavanja o sadržaju intervencija usmjerenih na promjenu ponašanja (prema Michie i sur., 2009; Albrecht i sur., 2013) koje uključuju osam deskriptora intervencija. Deskriptori se odnose na jasno i iscrpno opisivanje:

1. obilježja stručnjaka koji provode intervenciju

2. obilježja primatelja intervencije

3. obilježja okruženja u kojem se intervencija provodi

4. načina primjene intervencije

2 Primjerice, u intervencijama pod nazivom Multi-system Therapy, Homebuilders i Nurse-Family Partnership taj ključni sastojak je da se intervencije odvijaju u domu djeteta (prema Michie i sur., 2009).

3 WIDER - skraćenica za Workgroup for Intervention Development and Evaluation Research (Radna grupa za planiranje intervencija i evaluacijska istraživanja) 
Antonija Žižak, Miranda Novak, Valentina Kranželić, Anita Jandrić Nišević, Irma Kovčo Vukadin: Pojam i ključna obilježja kompleksnih intervencija za populacije u riziku

5. intenziteta (opseg kontakata)

6. trajanja (broj i učestalost susreta)

7. načina pridržavanja standarda intervencije (protokola) pri njenoj provedbi

8. sadržaja intervencije za svaku specifičnu skupinu klijenata/ korisnika s kojom je primijenjena.

\section{Što su kompleksne intervencije?}

Craig i suradnici (2008) navode da se kompleksne intervencije najčešće opisuje kao intervencije koje sadržavaju čitav niz komponenti tj. raznih dimenzija kompleksnosti: postoje razne interakcije među komponentama intervencije, postoji čitav niz složenih ponašanja koja se proučavaju u ciljnoj skupini, oni koji izvode intervenciju trebaju imati razne složene vještine, ciljna skupina ima zahtjevnu organizacijsku i grupnu strukturu, postoji čitav niz vrlo promjenljivih ishoda koje je teško mjeriti dok stupanj fleksibilnosti i prilagodbe intervencije raznim podgrupama ciljne populacije također varira u velikoj mjeri.

Hawe, Shiell i Riley (2004) definiraju kompleksnost kao znanstvenu teoriju koja pretpostavlja da određeni sustavi pokazuju ponašajne fenomene koji su posve neobjašnjivi konvencionalnim analizama pojedinih sastavnih dijelova sustava. Navode da su uz zdravlje djece i mladih ili pak školski kontekst često vezane nestandardne intervencije koje se ne može vrlo jasno rasporediti u određeni slijed aktivnosti jer obuhvaćaju izgradnju kapaciteta, odnosno kompetencija, organizacijske promjene, podizanje spremnosti zajednice i slično.

'Kompleksne intervencije se sastoje od većeg broja intervencijskih komponenti koje se mogu primjenjivati samostalno ili kao međuzavisna cjelina' (prema Hawe, Shiell i Riley, 2004).

'To su edukativne i psihosocijalne intervencije usmjerene na mijenjanje znanja, uvjerenja ili ponašanja' (Redfern, McKevitt i Wolf, 2006).

'Kompleksne socijalne intervencije karakteriziraju složeni protokoli postupanja, teško opisiva i različito motivirana populacija, različitosti među osobljem koje ih provodi te propusne vanjske granice koje uvjetuju da izvedba intervencije ovisi o socijalnom okruženju' (Lindsay, 2004) 
Antonija Žižak, Miranda Novak, Valentina Kranželić, Anita Jandrić Nišević, Irma Kovčo Vukadin: Pojam i ključna obilježja kompleksnih intervencija za populacije u riziku

'Kompleksne zdravstvene intervencije sastavljene su od nekoliko komponenti koje pri dosizanju željenih ciljeva mogu biti samostalne ili međuzavisne' (Wong, 2004).

'Kad je teško precizno odrediti „aktivne elemente intervencije" i njihov međusobni odnos vrlo je vjerojatno da se radi o kompleksnoj intervenciji' (prema Hawe, Shiell i Riley, 2004).

Analizom navedenih i drugih dostupnih definicija koje se koriste $u$ istraživačke i stručne svrhe (Datta i Petticrew, 2013, Evans i sur., 2013) moguće je utvrditi da se u pojam kompleksne intervencije uključuje veći broj obilježja intervencije. Budući da su ta obilježja važna za kreiranje operacionalne definicije od koje će se polaziti u ovom istraživanju navest ćemo ona koja se najčešće navode. Drugim riječima, da bi intervencija bila kompleksna važno je da uključuje/ omogućava:

- veći broj intervencijskih komponenti koje su u nekom međusobnom odnosu

- veći broj složenih ponašanja onih kojima su intervencije namijenjene i onih koji ih primjenjuju

- veći broj i veću varijabilnost (raznolikost, promjenljivost) ishoda intervencija

- $\quad$ promjene u sustavima kako bi se mogli ostvariti individualni ishodi ili ishodi na višoj razini (organizacija, grupa, sustav), odnosno kada je važno razumjeti u kakvoj su interakciji dijelovi sustava

- veći broj grupa ili organizacija na koje se intervencija odnosi

- veći stupanj fleksibilnosti i prilagodbe intervencije (nestandardnost)

- specifične, teorijski utemeljene procese.

Takva obilježja kompleksne intervencije (osobito činjenica da je sastavljena od nekoliko komponenti koje mogu djelovati i samostalno i u interakciji) otežavaju definiranje njenih 'aktivnih sastojaka'. Drugim riječima, nije uvijek i nije potpuno jasno koja komponenta izaziva promjenu i koja je kombinacija važnija (Shiell, Hawe i Gold, 2008). Petticrew (2011) navodi i druge izazove pri definiranju kompleksnih intervencija. Smatra da izazov nije u klasifikaciji intervencija nego u klasifikaciji perspektiva iz kojih se intervencije promatraju. Navodi da se intervencije ne mogu tako lako podijeliti na 'jednostavne' i 'kompleksne' (jer su sve intervencije složene), odnosno da se prije radi o jednostavnom ili kompleksnom opisu intervencija. Imajući to u vidu zaista je smisleno pitanje koje autor postavlja - kad su kompleksne intervencije stvarno 'kompleksne' i kada je korisno vidjeti ih i analizirati kao takve? 
Antonija Žižak, Miranda Novak, Valentina Kranželić, Anita Jandrić Nišević, Irma Kovčo Vukadin: Pojam i ključna obilježja kompleksnih intervencija za populacije u riziku

\section{Teorijska podloga kompleksnih intervencija}

Kao što navode Evans i sur. (2013) u pred-kliničkoj, odnosno teorijskoj fazi razvoja kompleksnih intervencija neophodno je, uz identificiranje najboljih intervencija koje već postoje u odgovarajućem području, identificirati i teorije koje su relevantna podloga nove intervencije kao i strategije njenog razvoja. $U$ tom smislu pretraživanje literature ukazuje da se pri planiranju, provedbi i evaluaciji kompleksnih intervencija najčešće koristi jedna od sljedeće tri teorije: teorija normalizacijskih procesa, teorija kompleksnosti i teorija promjene.

Teorija normalizacijskih procesa (Normalization Process Theory) sociološka je teorija nastala na istoimenom modelu kroz koji je operacionalizirana primjena kompleksne intervencije, a koji olakšava razumijevanje procesa koji se javljaju pri primjeni nekih kompleksnih tehnologija ili intervencija (May i Finch, 2009) i to najvećim dijelom u području zdravstva. Bavi se socijalnom organizacijom posla (implementacija), uključivanjem novih tehnologija/ stručnih tretmana i programa (uključivanje) te njihovom integracijom s postojećom praksom u nekom području (integracija). Slijedom toga teorija se bavi problemima procesne (primjena novih načina mišljenja, aktivnosti i organiziranja) i strukturne prirode (integriranje novih sustava prakse u postojeće organizacijske i profesionalne kontekste). Pod normalizacijom se razumije djelovanje koje dionici/ akteri obavljaju jer su dio neke zajedničke djelatnosti, a na temelju čega se ta djelatnost rutinizira te uključuje u mrežu postojećih, socijalno prihvaćenih (standardiziranih) znanja i praksi. Teorija naglašava da procesu normalizacije pridonose pojedinci i grupe (zajednice) ali da taj proces nikako ne može biti reduciran na individualne faktore.

Slijedom navedenog teorija pretpostavlja (May i Finch, 2009):

- nova praksa uključuje se u socijalni prostor neke djelatnosti kao rezultat individualnih ili grupnih/ kolektivnih napora ljudi koji ju primjenjuju (i pretvaraju u rutinsku djelatnost),

- dinamika prijenosa novih programa/ intervencija u neku postojeću praksu odvija se kroz četiri sveobuhvatna mehanizma (komponente teorije): usklađivanje, kognitivno sudjelovanje, zajedničke akcije, refleksivno praćenje,

- razvoj i održavanje prakse zahtijeva kontinuirano ulaganje uključenih aktera.

Teorija kompleksnosti (Complexity Theory) nastoji objasniti kompleksne sustave koristeći različite konstrukte. Integrira ideje preuzete iz teorije kaosa, kognitivne psihologije, informacijskih i kompjuterskih znanosti, evolucijske biologije, opće sistemske teorije. Naglašava da kompleksna 
Antonija Žižak, Miranda Novak, Valentina Kranželić, Anita Jandrić Nišević, Irma Kovčo Vukadin: Pojam i ključna obilježja kompleksnih intervencija za populacije u riziku

ponašanja počivaju na nekoliko jednostavnih pravila te da su svi kompleksni sustavi mreža međusobno zavisnih dijelova koji u interakciji slijede ta pravila.

Primjena ove teorije najprisutnija je u prirodnim znanostima (matematika, fizika, biologija) gdje počiva na matematičkim, ne-linearnim modelima. No, budući da se kompleksni sustavi proučavaju u različitim znanstvenim područjima često se umjesto o teoriji kompleksnosti govori o kompleksnim znanostima. Općenito se smatra da je teorija kompleksnosti izrasla iz opće teorije sustava (Ludwig von Bertalanffy) i Norbert Weinerovog kibernetičkog modela. Iz tih temelja proizlazi i razumijevanje ključnih obilježja kompleksnih sustava (Kaput i sur.2005; Sabelli, 2006):

- obilježja pojedinačnih, ali međusobno povezanih, elemenata/ ponašanja ne objašnjavaju se primarno svojstvima tih elemenata, nego svojstvima koja nastaju kroz njihovu interakciju;

- sustav nije linearan, oslanja se na feedback dijelova i sustava s okolinom te utječe na njihov razvoj;

- sustav djeluje istovremeno kroz više kanala i vremenskih okvira.

Pojednostavljeno govoreći, teorija kompleksnosti naglašava da sustav započinje kao skup pojedinačnih aktera koji se organiziraju te razvijaju međusobne odnose, koji nastaju kroz odgovore na pozitivne ili negativne povratne poruke nastale unutar ili izvan sustava. Problemi koji se teško rješavaju ujedno su i teško razumljivi. Pri rješavanju takvih problema djelovanje na jedan od njegovih aspekata može rezultirati promjenom u nekom drugom aspektu, zato što su dijelovi kompleksnih sustava međuzavisni. Stoga se u odnosu na kompleksne sustave s jedne strane istražuje: 1) kako interakcije potiču (nova) ponašanja; 2) razumijevanje načina na koji se kompleksni sustavi opisuju, te 3) proces izgradnje kompleksnih sustava kroz formiranje i razvoj uzoraka ponašanja (prema New England Complex Systems Institute).

Primjena različitih verzija i aspekata ove teorije u društvenim znanostima najprezentnija je u području sociologije gdje se osobito izdvaja doprinosi dvaju autora - Byrnea (1998) i Walby (2007). Byrne (2007) je više usmjeren na elaboriranje metodologije istraživanja kompleksnih sustava, odnosno načina na koje se podaci mogu sumativno sagledavati te na opisivanje specifičnih metodoloških pristupa koji omogućavaju sagledavanje sustava kao cjeline. Walby (2007) razmatra sličnosti i razlike između teorije sustava i teorije kompleksnosti te osobito 'studira' dinamičnost sustava (adaptivni sustavi), okruženje i njegov doprinos razvoju sustava i preklapanje dijelova sustava. Konstatira da se teorija sustava uklapa u kompleksne znanosti. Johnson (2008) razmatra povezanost ekološke teorije sustava i teorije kompleksnosti naglašavajući da istraživanja koja izučavaju razvoj pojedinca moraju uzeti u obzir ekološke i modele polja u kojima se u obzir uzimaju interakcije vezane uz pojedinaca, 
Antonija Žižak, Miranda Novak, Valentina Kranželić, Anita Jandrić Nišević, Irma Kovčo Vukadin: Pojam i ključna obilježja kompleksnih intervencija za populacije u riziku

kontekst i procese. Primjenu tih modela kao i teorije kompleksnosti vezuje uz dinamične sustave kakav je primjerice škola.

Teorija promjene razvijena je pod utjecajem znanstvenika koji su evaluirali programe te teoretičara $\mathrm{i}$ istraživača socijalnih promjena, odnosno promjena u zajednici. Stoga i ne postoji jedinstvena verzija ove teorije. Stavljajući teoriju promjene u samo ishodište modela evaluacije (na teoriji utemeljena evaluacija) Weiss (1995) daje jednostavan opis teorije kao skupa ideja koji omogućava da razumijemo kako, kada i zašto neki postupak dobro funkcionira. Postoji suglasnost o tome da ju je korisno primijeniti u fazi kreiranja i evaluacije programa i to u različitim kontekstima. Nadalje, postoji suglasnost da se ne radi o teoriji nego o pragmatičnom modelu, okviru (često grafičkom prikazu) koji (De Silva i sur., 2014) može biti dobra podloga za operacionalizaciju plana intervencije/ programa, odnosno njene implementacije i evaluacije.

Pregled literature u području kompleksnih intervencija ukazuje da je nužno kombinirati različite teorijske pristupe kako bi se objasnio što veći broj mehanizama koji utječu na njihovo planiranje, primjenu i evaluaciju (Angeles i sur., 2014). Jedna od tih teorija je Diffusion of Innovation Theory (Sahin, 2006; Angeles i sur., 2014). Analizirajući stanje glede teorijske utemeljenosti intervencija Michie i sur. (2008) konstatiraju da je to područje o kojem nema dovoljno informacija. Navode kako većini teorija koje teoretiziraju o tome kako dolazi do disfunkcije nedostaje dio koji objašnjava kako se ta disfunkcija mijenja pod utjecajem intervencije.

Sve navedeno govori u prilog konstatacije da je izbor teorijskog modela za razvoj kompleksnih intervencija veliki istraživački izazov.

\section{Kompleksni sustavi i kompleksne intervencije}

U svojim radovima Shiell, Hawe i Gold (2008) naglašavaju da termin 'kompleksno' ima dvostruko značenje: odnosi se na kompleksnost same intervencije ali i na kompleksnost sustava/okružja u kojem se intervencija primjenjuje.

Kompleksni sustavi su oni koji se mijenjaju i odgovaraju na promjene u svom neposrednom okružju te ih tvore drugi kompleksni sustavi (npr. obitelji ili specifične individue). Stoga se ne ponašaju na linearan i lako predvidljiv način. Primjerice, kompleksni sustavi uključuju zajednice, škole i radna mjesta u kojima intervencije mogu biti i jednostavne ili pak složene. Važno je pretpostaviti da bilo koja intervencija utječe na razne odnose unutar sustava te mijenja kontekst. To znači da 
Antonija Žižak, Miranda Novak, Valentina Kranželić, Anita Jandrić Nišević, Irma Kovčo Vukadin: Pojam i ključna obilježja kompleksnih intervencija za populacije u riziku

pri planiranju bilo koje intervencije u kompleksnom sustavu treba imati na umu šire posljedice interveniranja te pratiti odnose među komponentama same intervencije, ali i između intervencije i konteksta u koji se intervencija implementira. Shiell, Hawe i Gold (2008) smatraju da se radi o dva odvojena pristupa koja treba razlikovati, iako dijele neke sličnosti poput nestandardiziranosti, umnožavanja, preklapanja i brojnosti interakcija. Razlikovanje ta dva temeljna uzroka kompleksnosti omogućuje i bolje razumijevanje, analizu i evaluaciju intervencija.

U tom smislu Walshe (2007) se zalaže za napuštanje eksperimentalnog i prihvaćanje teorijski utemeljenog pristupa planiranju i evaluaciji kompleksnih socijalnih intervencija (u koje ubraja i one u području zdravstva). Pritom razlikuje nisku i visoku varijabilnost intervencija u odnosu na kontekst, sadržaj, primjenu te ishode intervencije te na taj način govori o primjeni intervencija u kompleksnim sustavima. Te su razlike prikazane u tablici što slijedi (Tablica 1).

Tablica 1 - Razine varijabilnosti (promjenljivosti) konteksta, sadržaja, primjene $i$ ishoda intervencije (prema Walshe, 2007, str. 58)

\begin{tabular}{|c|c|c|}
\hline $\begin{array}{l}\text { Promjenljiva obilježja } \\
\text { intervencije }\end{array}$ & $\begin{array}{l}\text { Niska varijabilnost - homogenost } \\
\text { (jednostavne intervencije) }\end{array}$ & $\begin{array}{l}\text { Visoka varijabilnost - } \\
\text { heterogenost } \\
\text { (kompleksne intervencije) }\end{array}$ \\
\hline $\begin{array}{l}\text { Kontekst (situacija, prostor, } \\
\text { organizacija u kojoj se } \\
\text { intervencija provodi) }\end{array}$ & $\begin{array}{l}\text { Obilježja slijede deterministički } \\
\text { obrazac - svi konteksti su isti ili } \\
\text { slični i ne mijenjaju se tijekom } \\
\text { vremena }\end{array}$ & $\begin{array}{l}\text { Značajne razlike postoje u } \\
\text { obilježjima konteksta i sustava te su } \\
\text { promjenljiva s vremenom, odnosno } \\
\text { tijekom provedbe intervencije }\end{array}$ \\
\hline $\begin{array}{l}\text { Sadržaj (priroda i obilježja } \\
\text { intervencije) }\end{array}$ & $\begin{array}{l}\text { Sadržaj je jasno specificiran i } \\
\text { standardiziran te gotovo istovjetan } \\
\text { pri ponavljanju }\end{array}$ & $\begin{array}{l}\text { Sadržaj intervencije prilagođen je } \\
\text { individualnoj izvedbi potrebama } \\
\text { pojedinca, grupe, organizacije te se } \\
\text { može mijenjati tijekom izvedbe }\end{array}$ \\
\hline $\begin{array}{l}\text { Primjena (proces kojim se } \\
\text { intervencija provodi) }\end{array}$ & $\begin{array}{l}\text { Proces je maksimalno ujednačen } \\
\text { u različitim izvedbama, uređen } \\
\text { protokolima i naputcima izvedbe }\end{array}$ & $\begin{array}{l}\text { Primjena ovisi o mnogim } \\
\text { promjenljivim elementima } \\
\text { (primjerice: profesionalne } \\
\text { vještine, iskustva uključenih, } \\
\text { odgovori korisnika intervencije na } \\
\text { uključivanje) }\end{array}$ \\
\hline Ishodi (rezultati intervencije) & $\begin{array}{l}\text { Postoji jedan, lako mjerljiv } \\
\text { ishod intervencije (primjerice: } \\
\text { preživljavanje kroz određeno } \\
\text { vrijeme) }\end{array}$ & $\begin{array}{l}\text { Mnogobrojni ishodi koji nisu lako } \\
\text { mjerljivi odnosno prepoznatljivi } \\
\text { (primjerice: razvoj, učenje, promjena } \\
\text { ponašanja na individualnoj ili } \\
\text { organizacijskoj razini) }\end{array}$ \\
\hline
\end{tabular}


Antonija Žižak, Miranda Novak, Valentina Kranželić, Anita Jandrić Nišević, Irma Kovčo Vukadin: Pojam i ključna obilježja kompleksnih intervencija za populacije u riziku

Slijedom navedenog, kada je neka kompleksna intervencija primijenjena u kompleksnom sustavu, posljedice te intervencije su višeslojne te se događaju na način da promjene u jednom dijelu sustava utječu na druge dijelove sustava, izmjenjujući povratne informacije. Upravo se te povratne informacije moraju uzeti u obzir u pristupu ovoj vrsti kompleksnosti: jer "ništa nije konstantno i sve je povezano sa svime ostalim" (Shiell, Hawe i Gold, 2008, str. 1283) te se promjene ne događaju u nekoj izolaciji od šireg okruženja. Isti autori naglašavaju da su posljedice promjena na razini sustava višestruke i umnožavaju se, s mnogobrojnim troškovima i ishodima, opsežnije nego što je početno bilo planirano u istraživačkim protokolima. Ključni izazov je bilježenje svih učinaka unutar procesa primjene i evaluacije. Razmatrajući proces studija isplativosti, Shiell, Hawe i Gold (2008) ističu da je tradicionalna postavka o nepromjenjivoj važnosti intervencije također pogrešna kada su u pitanju kompleksne intervencije u kompleksnim sustavima. Vrijednost intervencije mijenja se s dinamikom kompleksnog sustava te je važna funkcija intervencije da populacija više cijeni intervenciju nakon nego prije same primjene. Zbog toga je važno da metodološki pristupi na kojima se temelji planiranje i evaluacija intervencija uvaže socijalne determinante i vrijednosti okruženja. Literatura nudi brojne modele, pristupe ili okvire za planiranje intervencija općenito, ali i vrlo specifično, za planiranje kompleksnih intervencija unutar pojedinih intervencijskih sustava. Primjerice: medicinski model razvoja kompleksnih intervencija (Gerard i Taylor, 2004), model komponenti normalizacijskog procesa (May i sur., 2009; May i Finch, 2009), model teorije normalizacijskih procesa s okvirom za planiranje, evaluaciju i implementaciju kompleksnih intervencija (Murray i sur, 2010), model razvoja intervencija utemeljen na teoriji promjene (De Silva i sur., 2014). Među tim modelima postoje značajna preklapanja bez obzira na teorijsko utemeljenje. Stoga će u narednim fazama za rada na projektu biti važno analizirati te modele i pristupiti njihovoj prilagodbi temeljem dobivenih rezultata.

\section{ŠTO SMO NAUČILI IZ LITERATURE}

Kao što je uvodno istaknuto, cilj pregleda literature koja se bavi kompleksnim intervencijama, i uz njih vezanim konstruktima i teorijskim pristupima, odnosi se na predstavljanje ključnih točaka važnih za razumijevanje tog konstrukta te osmišljavanje i predstavljanje definicije kompleksnih intervencija koja će se u ovom istraživačkom projektu koristiti. 
Antonija Žižak, Miranda Novak, Valentina Kranželić, Anita Jandrić Nišević, Irma Kovčo Vukadin: Pojam i ključna obilježja kompleksnih intervencija za populacije u riziku

\section{Operacionalne definicije}

Za nastavak rada na istraživačkom projektu Specifična obilježja obitelji u riziku: doprinos razvoju kompleksnih intervencija važno je prihvatiti operacionalne definicije pojmova kompleksne potrebe i kompleksne intervencije. Nakon analize dostupne literature istraživački tim dogovorio je sljedeće operacionalne definicije:

\section{KOMPLEKSNE POTREBE}

Kompleksne potrebe člana obitelji i/ili obitelji postoje ako:

- jedan ili više članova obitelji istovremeno ima probleme u dva ili više životnih područja (školskog postignuća, napuštanja škole, ponašanja i emocija, mentalnog zdravlja, zlouporabe sredstava ovisnosti i/ili alkohola, zlostavljanja i zanemarivanja, ponašanja kojima se krši zakon ili drugih područja)

- jedan, više članova ili cijela obitelj zbog tih problema istovremeno ima potrebu za podrškom, tretmanom ili intenzivnim nadzorom koji su organizirani kroz intervencije/ usluge dva ili više intervencijskih sustava (socijalne skrbi, zdravstvene i mentalno zdravstvene skrbi, tretmana zlouporabe alkohola ili drugih sredstva ovisnosti, odgoja i obrazovanja te pravosuđa).

KOMPLEKSNE INTERVENCIJE

Intervencija će se smatrati kompleksnom ako:

- sadržava najmanje dvije intervencijske komponente (odnosno jednostavne intervencije) koje su u nekom međuodnosu,

- usmjerena je prema pojedinom članu i/ili obitelji kao sustavu,

- usmjerena je na postizanje većeg broj varijabilnih (raznolikih i promjenljivih) ishoda,

- zahtijeva, odnosno provodi se u koordinaciji najmanje dva intervencijska sustava (odgoj i obrazovanje, pravosuđe, socijalna skrb, zdravstvo). 
Antonija Žižak, Miranda Novak, Valentina Kranželić, Anita Jandrić Nišević, Irma Kovčo Vukadin: Pojam i ključna obilježja kompleksnih intervencija za populacije u riziku

\section{Smjernice za planiranje i provedbu istraživanja}

Prikazani pregled saznanja o kompleksnim intervencijama omogućava da se kao važan doprinos za naredne faze istraživanja izdvoje sljedeće smjernice:

- Procjena potreba za intervencijom osoba/obitelji s kompleksnim problemima/ potrebama odvija se na različite načine (po različitim modelima). U pravilu se ti modeli temelje na procjeni potreba od strane pojedinih članova obitelji (samporocjena) (Walsh, 2007). Drugim riječima, izuzetno je važno intervencije temeljiti i na doživljaju/ percepciji vrste i složenosti vlastitih problema / potreba od strane pojedinih članova, koje se potom stavljaju u kontekst obitelji.

- Podatke o kompleksnim potrebama pojedinaca i obitelji potrebno je prikupiti iz više relevantnih izvora.

- Pri istraživanju s obiteljima s kompleksnim potrebama važno je u istraživanje uključiti manji broj obitelji s usporedivim vrstama kompleksnih problema / potreba (Maras i sur., 2008).

- Postojeće intervencije poželjno je opisati iz stručne perspektive prema standardiziranim deskriptorima te iz subjektivne perspektive korisnika intervencija (Michie i sur., 2009).

- Za praćenje promjena na razini intervencijskog konteksta/ sustava važno je istražiti i opisati kako se specifična intervencija uklapa u sustav intervencija (Hawe, Shiell i Riley, 2009).

- Za praćenje promjena na razini obiteljskog sustava tijekom intervencije važno je istražiti i opisati promjene u resursima (odnosima, vještinama, ponašanjima i sl.) obitelji i članova obitelji (Hawe, Shiell i Riley, 2009). 
Antonija Žižak, Miranda Novak, Valentina Kranželić, Anita Jandrić Nišević, Irma Kovčo Vukadin: Pojam i ključna obilježja kompleksnih intervencija za populacije u riziku

\section{LITERATURA}

Albrecht, L., Archibald, M., Arseneau, D., Scott, S. (2013): Development of a checklist to assess the quality of reporting of knowledge translation interventions using the Workgroup for Intervention Development and Evaluation Research (WIDER) recommendations. Implementation Science. 88 (52). Open Access Short Report. htpp://Www. implementationscience.com/content/8/1/52

Angeles, R.N., Dolovich, L., Kaczorowski, J., Thabane, L. (2014): Developing a theoretical framework for complex community-based interventions. Health Promotion Practice. 15 (1). $100-$ 108.

Alhadeff-Jones, M. (2008): Three generations of complexity theories: Nuances and ambiguities. U: Mason, M. (ur.), Complexity theory and the philosophy of education. Oxford: Blackwell-Wiley. 62-78.

Benning C.L., Lahm, K.F. (2016): Effects of parent-child relationships on inmate behavior: a comparison of male and female inmates. International Journal of Offender Therapy and Comparative Criminology. 60 (2). 189-207.

Bernstein, N. (2003): Bill of rights for children of incarcerated parents. San Francisco Partnership for Incarcerated Parents (SFPIP). http://www.fcnetwork.org/billofrights.pdf

Blumberg, D.M., Griffin, D.A. (2013): Family connections: the importance of prison reading programs for incarcerated parents and their children. Journal of Offender Rehabilitation. 52 (4). 254-269.

Bromfield, L., Sutherland, K., Parker, R. (2012): Families with multiple and complex needs. Melbourne, Australia: Victoria Government Department of Human Services.

Brown, A.L. (1992): Design Experiments: Theoretical and methodological challenges in creating complex interventions in classroom setting. The Journal of the Learning Sciences. 2 (2). 141-178.

Bülow, W. (2014): The harms beyond imprisonment: do we have special moral obligations towards the families and children of prisoners? Ethical Theory and Moral Practice. 17 (4). 775-789.

Byrne, D. (1998): Complexity theory and the social sciences: An introduction. London and New York: Routledge. 
Antonija Žižak, Miranda Novak, Valentina Kranželić, Anita Jandrić Nišević, Irma Kovčo Vukadin: Pojam i ključna obilježja kompleksnih intervencija za populacije u riziku

Campbell M., Fitzpatrick R., Haines A., Kinmonth, A.L. et all (2000): Framework for the design and evaluation of complex interventions to improve health. British Medical Journal. 321. 694-696.

Casey-Acevedo, K., Bakken, T., Karle, A. (2004): Children visiting mothers in prison: the effects on mothers' behaviour and disciplinary adjustment. The Australian and New Zealand Journal of Criminology. 37 (1). 418-430.

Cohen, D.J. (1995): Psychosocial therapies for children and adolescents: Overview and future directions. Journal of Abnormal Child Psychology. 23 (1). 141-152.

Craig, P., Dieppe, P., Macintyre, S., Michie, S., Nazareth, I., Petticrew, M. (2008): Developing and evaluating complex interventions: The new Medical Research Council guidance. British Medical Journal. 337 (a1). 655.

Datta, J., Petticrew, M. (2013). Challenges to evaluating complex interventions: a content analysis of published papers. BMC Public Health. 13. 568. Open Access Research Article. http://www.biomedcentral.com/1471 - 2458/13/568

Davis, B. (2008): Complexity and education: vital simultaneities. U: Mason, M. (ur.): Complexity theory and the philosophy of education. A John Wiley \& Sons. Ltd., Publications. 46-61.

De Claire, K., Dixon, L. (2015): The effects of prison visits from family members on prisoners' wellbeing, prison rule breaking, and recidivism: a review of research since 1991. Trauma, Violence and Abuse. DOI: 10.1177/1524838015603209

De Silva, M., Breuer, E., Lee, L., Asher, L., Chowdhary, N., Lund, C., Patel, V. (2014): Theory of change: a theory-driven approach to enhance the medical research council's framework for complex interventions. Trials.15 - 267. http:// www.trialsjournal.com/ content/15/1/267

Egan, M., Bambra, C., Petticrew, M., Whitehead, M. (2009): Reviewing evidence on complex social interventions: appraising implementation in systematic reviews of the health effects of organizational-level workplace interventions. Journal of Epidemiologic Community Health. 63. 4-11.

Evans, C.J., Stone, K.A., Manthorpe, J., Higginson, I.J. (2013): MRC guidance on developing and evaluation complex interventions: Application to research on palliative and end of life care. London: NIHR School for Social Cere Research and London School of Economics and Political Science. 
Antonija Žižak, Miranda Novak, Valentina Kranželić, Anita Jandrić Nišević, Irma Kovčo Vukadin: Pojam i ključna obilježja kompleksnih intervencija za populacije u riziku

Gabelica Šupljika, M. (ur.) (2009): Prava djece čiji su roditelji u zatvoru. Pravobranitelj za djecu. Zagreb.

Gampell, L., Scharff-Smith, P. (2011): Children of imprisoned parents. Jes Ellehauge Hansen. Denmark.

Genty, P. M. (2012): Moving beyond generalizations and stereotypes to develop individualized approaches for working with families affected by parental incarceration. Family Court Review. 50 (1). 36-47.

Gorard, S., Taylor, C. (2004): Combining methods in educational and social research. Maidenhead, England: Open University Press.

Hawe, P., Shiell, A., Riley, T. (2004): Complex interventions: how out of control can a randomized controlled trial be? British Medical Journal. 328 (7455): 1561-1563.

Hissel, S., Bijleveld, C., Kruttchnitt, C. (2011): The well-being of children of incarceated mothers: an exploratory study for Netherlands. European Journal of Criminology. 8 (5). 346-360.

Hoagwood, K.E. (2005): Family-based services in children's mental health: a research review and synthesis. The Journal of Child Psychology and Psychiatry and Allied Disciplines. 46 (7). 690-713.

Hoge, R.D. (1999): Assessing adolescents in educational, counseling, and other settings. Mahwah: Lawrence Erlbaum Associates, Publishers.

Human Service [Complex Needs] Act 2009: No. 16 of 2009. http://www.legislation.vic.gov.au/ domino/web_notes/ldms/pubstatbook.nsf/f932b66241ecf1b7ca256e92000e23be/37D 00D7BC1C7AD5BCA2575B4001A787A/\$FILE/09-16a.pdf

Jelavić, M. (2009): Obiteljskopravna i socijalna zaštita djeteta čiji je roditelj u zatvoru. U: Gabelica Šupljika, M. (ur.), Prava djece čiji su roditelji u zatvoru. Zagreb: Pravobranitelj za djecu. 47-56.

Johnson, E.S. (2008): Ecological systems and complexity theory: toward an alternative model of accountability in education. Complicity: An International Journal of Complexity and Education. 5 (1). 1-10.

Kandal, S., Rodger, J., Palmer, H. (2010): The use of whole family assessment to identify the needs of families with multiple problems. Research report DEF-RR045. UK Government, Department for Education. 
Antonija Žižak, Miranda Novak, Valentina Kranželić, Anita Jandrić Nišević, Irma Kovčo Vukadin: Pojam i ključna obilježja kompleksnih intervencija za populacije u riziku

Kaput, J., Bar-Yam, Y., Jacobson, E., Lemke, J., Wilensky, U. and Collaborators (2005): Planning documents for a national initiative on complex systems in $\mathrm{k}-16$ education. Posjećeno 28. ožujka 2016. na http://www.necsi.edu/events/cxedk16/cxedk16.html

Katz, I., Spooner, C., Valentine, K. (2006): What interventions are effective in improving outcomes for children of families with multiple and complex problems? Australian Research Alliance for Children and Youth, West Perth, WA.

Keene, J. (2001): Client with complex needs: Interprofessional practice. Oxford: Blackwell Science.

King, D. (2002): Parents, children and prison: effects of parental imprisonment on children. Combat Poverty Agency. Ireland.

Lindsay, B. (2004): Randomized controlled trials of social complex nursing interventions: creating bias and unreliability? Journal of Advanced Nursing. 45 (1). 84-94.

Loper, A.B., Whalen, M., Will, J. (2015): Inside and out. Family life for parents in prison. U: Arditti, J.A. (ur.), Family problems: stress, risk, and resilience. West Sussex, UK: Wiley Blackwell, 50-67.

Loper, A.B., Carlson, W., Levitt, L., Scheffel, K. (2009): Parenting stress, alliance, child contact, and adjustment of imprisoned mothers and fathers. Journal of Offender Rehabilitation. 48. 483-503.

Maras, P., Bradshaw, V., Croft, C., Gale, L., Webb, J. (2008): Working with families with complex needs. A multi-agency approach. London: The University of Greenwich, School of Health and Social Care. Posjećeno 15. ožujka 2016 na http://www.gre.ac.uk/_data/ assets/pdf_file/0008/652616/families-final-report.pdf

Markson, L., Lamb, M.E., Lösel, F. (2015): The impact of contextual family risks on prisoners' behavioural outcomes and the potential protective role of family functioning moderators. European Journal of Developmental Psychology, DOI: 10.1080/17405629.2015.1050374

May, C. i Finch, T. (2009): Implementing, embedding, and integrating practices: An outline of Normalization Process. Theory Sociology. 43 (3). 535-554.

May, C.R., Mair, F., Finch, T., MacFarlane, A., Dowrick, C., Treweek, S., Rapley, T., Ballini, L., Nio Ong, B., Rogers, A., Murray, E., Elwyn, G., Legare..., F., Gunn, J., Montori, V.M. (2009): Implementation Science. 4. 29. Open Access.

Medical Research Council (2008): Developing and evaluating complex interventions: New Guidance. London: Medical Research Council. 
Antonija Žižak, Miranda Novak, Valentina Kranželić, Anita Jandrić Nišević, Irma Kovčo Vukadin: Pojam i ključna obilježja kompleksnih intervencija za populacije u riziku

Michie, S., Johnston, M., Francis, J., Hardeman, W., Eccles, M. (2008): From theory to interventions: mapping theoretically derived behavioural determinants to behaviour change techniques. Applied Psychology. 57 (4). 660-680.

Michie, S., Fixsen, D., Grimshaw, J.M., Eccles, M.P. (2009): Specifying and reporting complex behaviour interventions: the need for a scientific method. Implementation Science. 4. 40. Open Access.

Michie, S., Prestwich, A. (2010): Are interventions theory-based? Development of Theory coding scheme. Health psychology. 29 (1). 1-8.

Michie, S., Johnston, M. (2012): Theories and techniques of behavior change. Developing a cumulative science of behavior change. Health Psychology Review. 6 (1). 1-6.

Mosgen, D., Klein, M. (2015): Children and spouses of aubstance abusers: Stress, strain, and interventions. Lisbon Addictions Conference, 23.09.2015.

Morris, K., Hughes, N., Clarke, H., Tew, J., Mason, P., Galvani, S., Lewis, A., Loveless, L., Becker, S., Burford, G. (2008): Think family: A literature review of whole family approaches. Great Brittan, Cabinet Office, Social Exclusion Task Force.

Murray, E., Treweek, S., Pope, C., MacFarlane, A., Ballini, L., Dowrick, C., Finch, T., Kennedy, A., Mair, F., O'Donnell, C., Nio Ong, B., Rapley, T., Rogers, A., May, C. (2010): Normalization process theory: a framework for developing, evaluating and implementing complex interventions. BMC Medicine. 8. 63. Open Access.

Murray, J. (2007): The cycle of punishment: social exclusion of prisoners and their children. Criminology and Criminal Justice, DOI: 10.1177/1748895807072476.

Murray, J., Farrington, D.P. (2008): The effects of parental imprisonment on children. U:Tonry, M. (ur.), Crime and justice: a review of research. Chicago, IL: University of Chicago Press. 133-206.

Murray, J., Farrington, D. P., Sekol, I., Olsen, R. F. (2009): Effects of parental imprisonment on child antisocial behaviour and mental health: A Systematic Review. Campbell Systematic Reviews.

Murray, J., Farrington, D. P., Sekol, I. (2012): Children's antisocial behavior, mental health, drug use, and educational performance after parental incarceration: a systematic review and meta-analysis. Psychological Bulletin, 138 (2). 175-210.

New England Complex Systems Institute. http://www.necsi.edu/guide/ Posjećeno 28.03.2016. 
Antonija Žižak, Miranda Novak, Valentina Kranželić, Anita Jandrić Nišević, Irma Kovčo Vukadin: Pojam i ključna obilježja kompleksnih intervencija za populacije u riziku

O'Hare, T. (2009): Essential skills of social work practice: Assessment, interventions, evaluation. Chicago: Lyccum Books, Inc.

Petticrew, M. (2011): When are complex interventions 'complex'? When are simple interventions 'simple'? European Journal of Public Health. 21 (4). 397-399.

Philbrick, K., Ayre, L., Lynn, H. (ur.) (2014): Children of imprisoned parents. European perspectives on good practice. Paris: Children of prisoners Europe.

Phillips, S.D., Burns, B.J., Wagner, H.R., Kramer, T.L., Robbins, J.M. (2002): Parental incarceration among adolescent receiving mental health services. Journal of Child and Family Studies. 11 (4). 385-399.

Poehlmann, J. (2005): Representations of Attachment Relationships in Children of Incarcerated Mothers. Child Development. 76 (3). 679-696.

Poehlmann J. (2005): Incarcerated mothers' contact with children, perceived family relationships, and depressive symptoms. Journal of Family Psychology. 19 (3). 50-357.

Profaca, B., Buljan Flander G. (2009): Podrška djetetu čiji je roditelj u zatvoru. U Gabelica Šupljika, M. (ur.), Prava djece čiji su roditelji u zatvoru. Zagreb: Pravobranitelj za djecu. 32-46.

Rankin, J., Regan, S. (2004): Meeting complex needs: The future of social care. London: The Institute for Public Policy Research and Turning Point.

Roberston, O. (2007): The impact of parental imprisonment on children. Geneva: Quaker United Nations Office

Rosenberg, J. (2009): Children need dads too: Children with fathers in prison. The Quaker United Nations Office. Geneva.

Redfern, J., McKevitt, C. i Wolf, C.D.A. (2006): Development of complex interventions in stroke care: A system review. Review of Complex Interventions in Stroke Care. 37. 2410-2419.

Rosengard, A., Laing, I., Ridley, J., Hunter, S. (2007): A literature review on multiple and complex needs. Scottish Executive Social Research. Posjećeno 23. ožujka 2016. na www. scotland.gov.uk/socialresearch.

Sabelli, N.H. (2006): Complexity, technology, science, and education. The Journal of Learning Sciences. 15 (1) 5-9.

Sahin, I. (2006): Detailed review of Rogers' diffusion of innovations theory and educational technology-related studies based on Rogers' theory. The Turkish Online Jurnal of Educational Technology. 5 (2). 14-23. Article 3. 
Antonija Žižak, Miranda Novak, Valentina Kranželić, Anita Jandrić Nišević, Irma Kovčo Vukadin: Pojam i ključna obilježja kompleksnih intervencija za populacije u riziku

Shiell, A., Hawe, P., Gold, I. (2008): Complex interventions or complex systems? Implications for health economic evaluation. British Medical Journal. 336. 1281-1283.

Snyder, S. (2013): The simple, the complicated, and the complex: Educational reform through the lens of Complexity theory. EOCD Education Working Papers. No.96, OECD Publishing. Posjećeno 01. ožujka 2016. na http://dx.doi.org/10.1787/5k3txnpt1/nr-en

Terry, L., Scott, G., Khan, L. (2015): Comprehensive services for complex needs: assessing the evidence for three approaches. London: Revolving Doors Agency.

The Calouste Gulbenkian Foundation (UK Branch) and Makin Every Adult Matter (MEAM)(2015): Individuals with multiple needs: the case for a national focus. Posjećeno 01. veljače 2016. na http://www.gulbenkian.org.uk/

Thoburn, J. (2009): Effective interventions for complex families where there are concerns about, or evidence of, a child suffering significant harm. Briefing paper 1. London: Center for Excellence and Outcomes in Children and Young People's Services (C4EO).

Walby, S. (2007): Complexity theory, System theory, and multiple intersecting social inequalities. Philosophy of Social Sciences. 37 (4). 449-470.

Walshe, K. (2007): Understanding what works - and why - in quality improvement: the need for theory-driven evaluation. International Journal for Quality in Health Care. 19 (2). 5759.

Weiss, C. H. (1995): Nothing as practical as good theory: exploring theory-based evaluation for comprehensive community initiatives for children and families. U: Connell, J.P., Kubisch, A.C., Schorr, L.B. and Weiss, C.H. (ur), New approaches to evaluating community initiatives: concepts, methods, and contexts. New York: The Aspen Institute, 65-92.

Whittaker, J.K., Tracy, E.M. (1989): Social treatment. Second edition. New York: Aldine de Gruyter.

Wong, I.C.K. (2004): Randomized controlled trials (RCTs) to evaluate complex healthcare interventions - a case study. Pharmacy World and Science. 26 (5) 247-252. 
Antonija Žižak, Miranda Novak, Valentina Kranželić, Anita Jandrić Nišević, Irma Kovčo Vukadin: Pojam i ključna obilježja kompleksnih intervencija za populacije u riziku

\section{The key caracteristics of complex interventions for populations at risk ${ }^{4}$}

\section{Summary}

This article is part of the project Specific characteristics of families at risk: contribution to complex interventions planning which is conducted at The University of Zagreb, Faculty of Education and Rehabilitation Sciences. The project is fully financially supported by Croatian Scientific Foundation under the Research Projects 2014. The aim of this paper is to find out, present and discuss different meanings and understandings of complex interventions, as well as theories and models they are based on. The final purpose of that presentation is to construct operational definition of complex interventions that is going to be used in this project. Literature on complex needs, problems and populations was reviewed parallel to literature covering complex intervention and complex interventional systems in the domain of education, health, especially mental health, social welfare and justice. After that, operational definitions of the notions of complex (individual and family) needs and complex interventions, as well as recommendations for planning and implementing research procedure were presented

Key words: complex needs; complex population; complex interventions

4 This work has been fully supported by Croatian Scientific Foundation under the project IP-2014-09-9515. 